\title{
液晶ディスプレイ用冷陰極蛍光ランプの技術動向
}

Technical Trends of Cold-Cathode Fluorescent Lamps for L.C.D. Display

\キーワード：冷陰極蛍光ランプ, 細管化, 長寿命化, 高効率化, EEFL, 希ガス放電

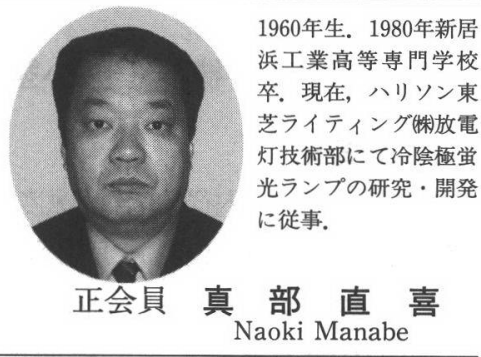

1.はじめに

液晶ディスプレイの市場は，情報機器の高性能化・多 機能化・大型化に伴い，急激に拡大している。従来は主 としてノート PCを中心に実用化されてきたが，最近で は携帯電話に代表されるモバイル機器用の小型用途から CRT 置き換えを狙った大型 TV 用途まで幅広く採用さ れるようになってきている.

これらのディスプレイのバックライト光源として，冷 陰極蛍光ランプが主流として用いられている．近年では ディスプレイ用途が拡大するにつれ冷陰極蛍光ランプに も用途に応じた機能が求められるようになってきてお り，さらに位置づけもディスプレイの表示性能はもちろ ん，消費電力・厚さ・重量などに大きな影響を与えるの で，その商品価值を決定するキーパーツとなっている.

本稿ではバックライト用冷除極蛍光ランプの最近の技 術動向について述べる。

\section{2. バックライトユニットの方式}

バックライトユニットの構造は, 大別してサイドライ
ト方式と直下方式の 2 種類があり各々の用途に応じて使 い分けられている。

図 1，表 1 にそれぞれのバックライトユニットの構造 例や使用ランプを示す．各々，用途に応じたバックライ トユニット方式やそれに使用されるランプの管径/本数 が使い分けられている。

\section{1 サイドライト方式}

導光板の側面にランプを配置する方式である．光の利 用効率は $50 \%$ 前後であるものの, 薄型で輝度の均斉度に 優れ，軽量のため持ち運びできる利点がある。従来はラ ンプ1本を具備した 15 インチ以下のモバイル機器・中小 型機器に用いられてきた (図 1(a))。最近では大型モ二 ター用途の15インチから20インチサイズにまで採用さ れているが, ランプ1本では必要な光量が得られないた め，両サイドに各 1 ～ 3 本（合計 $2 \sim 6$ 本）のランプを 配置した方式がとられている(図 1(b)).

\section{2 直下方式}

拡散板の直下に複数のランプを配置する方式である (図 1 (c)). 光利用効率は $60 \%$ 以上あり, 主に高輝度を要 求される大型モ二ター・大型 TV 用途に採用されている.

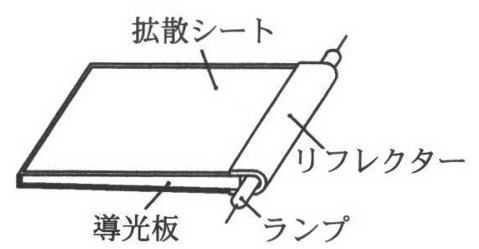

(a) サイドライト方式（1灯使用）

[モバイル機器, 中・小型民生機器]

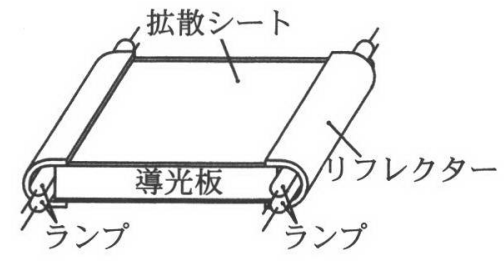

（b）サイドライト方式（多灯使用）

[大型モニター・大型TV用途]

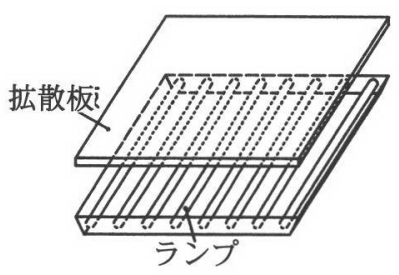

(c) 直下方式（多灯使用） [大型モニター・大型TV用途］

図 1 バックライトユニットの構造・ランプ使用例

表 1 バックライトユニットのランプ使用例

\begin{tabular}{|c|c|c|c|c|}
\hline \multicolumn{2}{|c|}{ 用 途 } & $\begin{array}{c}\text { モバイル機器 } \\
\text { 中・小型民生機器 }\end{array}$ & $\begin{array}{c}\text { 大型モニター } \\
\text { (大型 TV) }\end{array}$ & $\begin{array}{c}\text { 大型 TV } \\
\text { (大型モニター) }\end{array}$ \\
\hline \multicolumn{2}{|c|}{ 液晶ディスプレイサイズ } & 15インチ以下 & 15２0インチ & 20インチ以上 \\
\hline \multicolumn{2}{|c|}{ バックライト方式 } & サイドライト方式 & サイドライト方式 & 直下方式 \\
\hline \multirow{2}{*}{$\begin{array}{l}\text { 冷 } \\
\text { 隍 } \\
\text { 嗫 } \\
\text { 当 } \\
\text { 光 } \\
\text { プ }\end{array}$} & 使用本数 & 1 本 & $\begin{array}{l}\text { (片側 } 1 \sim 3 \text { 本) } \\
\text { 合計 } 2 \sim 6 \text { 本 }\end{array}$ & $8 \sim 20$ 本 \\
\hline & ランプ径 & $\phi 1.6 \sim 2.0 \mathrm{~mm}$ & $\phi 2.2 \sim 2.6 \mathrm{~mm}$ & $\phi 2.6 \sim 4.0 \mathrm{~mm}$ \\
\hline
\end{tabular}




\section{3. モバイル機器・中小型民生機器への対応}

\section{1 細管化}

図 2 にランプ内径別相対輝度・全光束の関係を示す。 輝度はランプ内径にほぼ反比例して増加する。サイドラ イト方式ではこのことが細管化に伴う導光板への光の入 射効率の向上と相まって板面輝度を高める点で有効と なった。

薄型化が重要視されるサイドライト方式のバックライ トユニットに扔いては，15亿ンチクラスで外径 ф1.8 2.0mm のランプが主流を占めており，8インチ 以下のクラスでは外径 $\phi 1.6 \mathrm{~mm}$ までが使用されてい る. 今後, ユニットの薄型・軽量化はさらに加速される と考之られ, 外径 $\phi 1.2 \sim 1.4 \mathrm{~mm}$ の極細管冷㓌極蛍光う ンプが検討されている.

\section{2 高効率化}

\section{(1) ガラス管肉厚の最適化}

冷㓌極蛍光ランプは管内に封入されている水銀の紫外 線放射を利用しているため，発光効率は水銀蒸気圧，つ まりランプ管壁温度に大きく依存される．また，その温 度が約 $65^{\circ} \mathrm{C}$ の時に発光効率はピークを示す．従って，高 効率化を実現するためにはランプが使用される条件に応 じて管壁温度を $65^{\circ} \mathrm{C} に$ 近づける必要があり，ランプ径や 封入がス種などのランプ設計を最適化することが重要で ある。

低電力領域での高効率化を狙い，ガラス管の薄肉化が 行われている1). 図3にガラス管肉厚の異なるランプを バックライトユニットに組み込んだ際のランプ電力別相

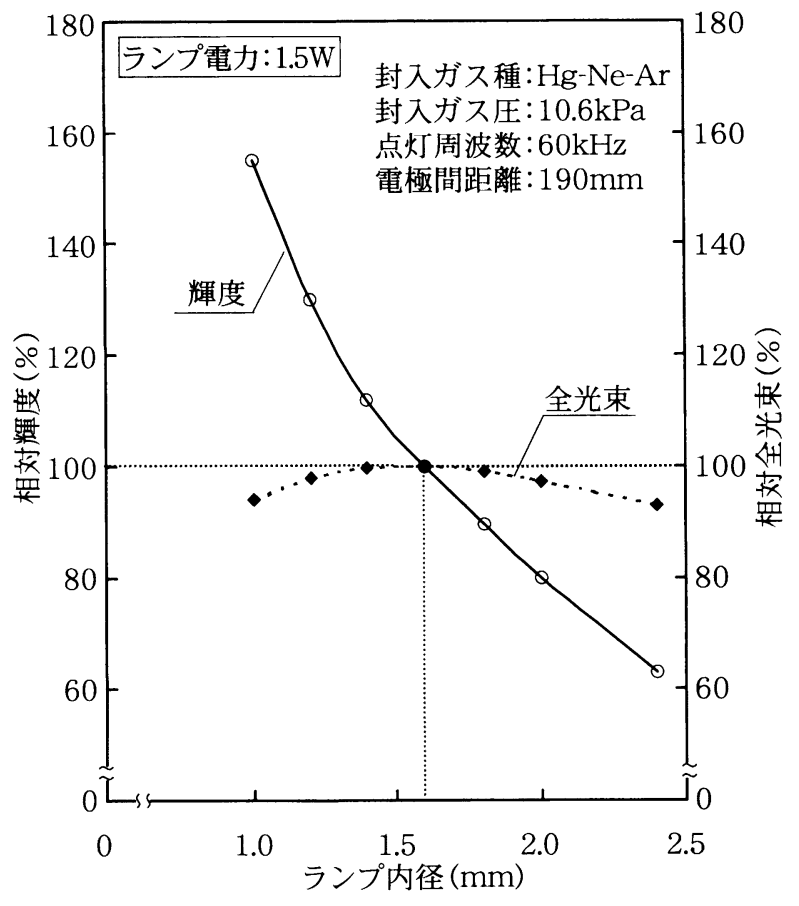

図 2 ランプ内径別輝度・全光束特性

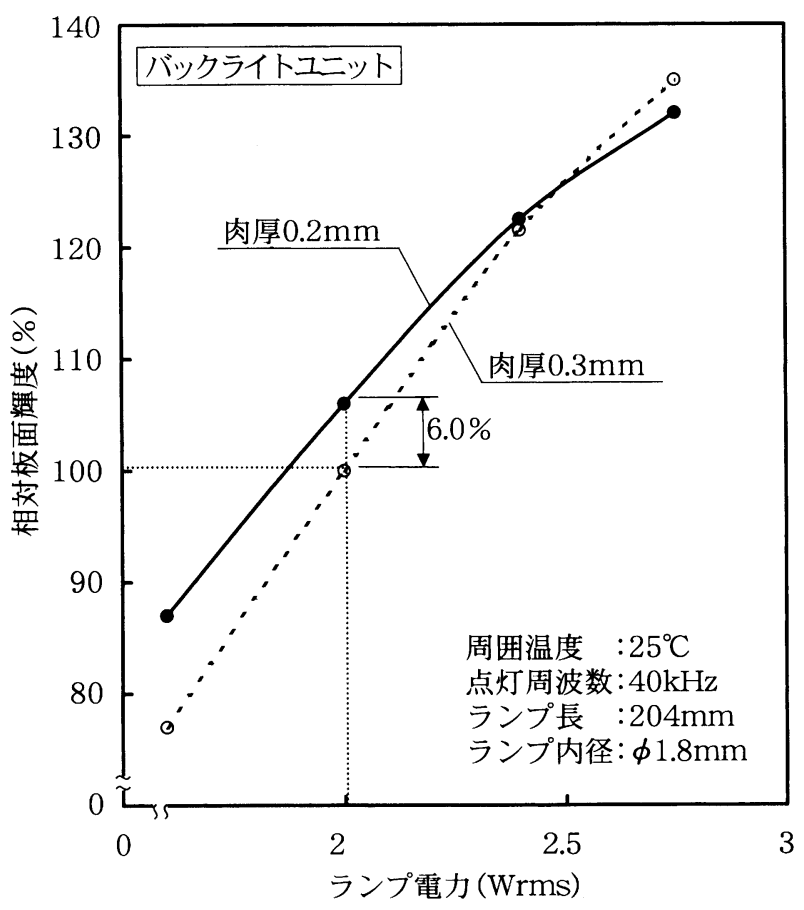

図 3 ランプ電力と相対板面輝度の関係

対板面輝度を示すランプ電力が低い領域ではがラス管 肉厚が薄い程高効率になっている。これは，肉厚を薄く することにより管壁温度，すなわち水銀蒸気圧が上昇し やすくなりランプ自体の発光効率が上昇し，さらにラン プ外径の縮小による導光板への光の入射効率向上も寄与. していると考えられる。現在では，モバイル機器・中小 型民生機器に採用される外径 $\phi 2.0 \mathrm{~mm}$ 以下のランプで はガラス肉厚 $0.2 \sim 0.25 \mathrm{~mm}$ が主流である.

(2) 陰極降下電圧の低減

冷陰極蛍光ランプは，電極に高電圧を印加して 2 次電 子放出によって電子を放電空間へ放出させる機構のため 陰極降下電圧は130１40V と高い。この対策として，仕 事関数の低い物質（以下，「エミッ夕」と称寸。）を電極上 に形成して陰極降下電圧を低減させる試みが続けられて いる ${ }^{23)}$. 物質はイットリウム化合物, バリウム化合物, ランタン化合物，セシウム化合物などがあるが，冷陰極 蛍光ランプの場合，イオン衝撃による電極のスパッタリ ングの影響でエミッタが飛散してしまう。このため，エ ミッタによる陰極降下電圧低減効果を 10000 時間以上確 保することが困難であり，ゲーム機器やビデオカメラな どそれほど長寿命を要求されない分野で採用されてい る. 今後も, 低電力化の要求に対してエミッ夕塗布電極 は有力な手段であり，より一層の長寿命化が望まれてい る。

最近では電極構造を有底円筒型にしてホローカソード 効果による陰極降下電圧低減を狙った構造が主流であ る.ささに電極材質を変更する開発も進んでいる ${ }^{4)}$. 図 4 に各種電極材質別電流一電压特性を示す．従来のニッケ 


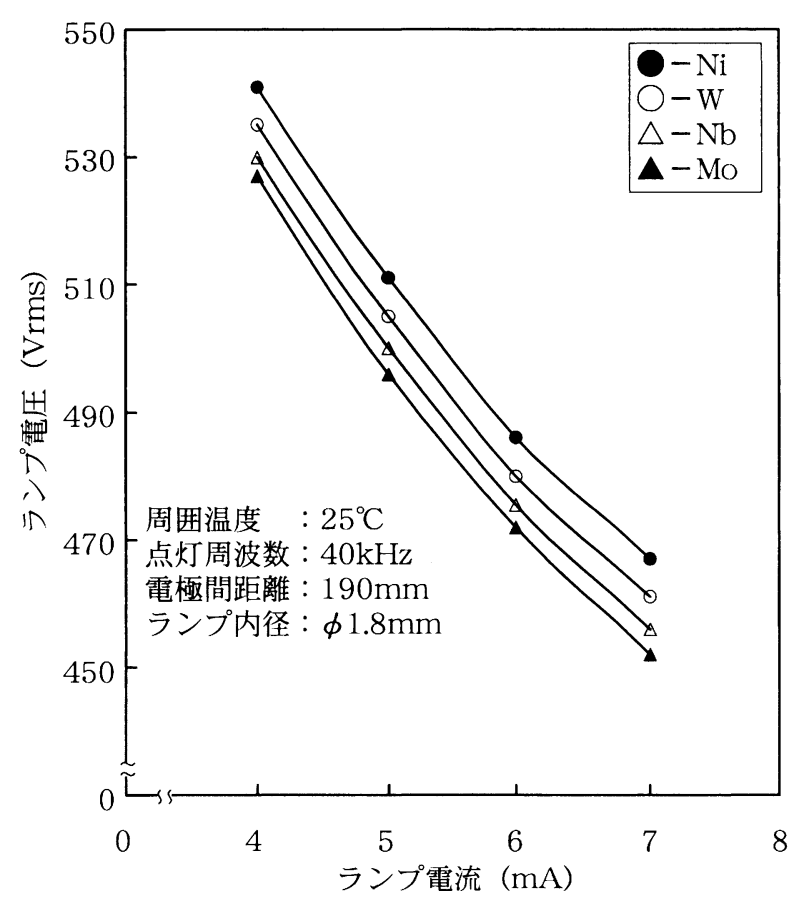

図 4 電極材質別ランプ電流とランプ電圧の関係

ル電做をモリブデンに変更することにより約 $20 \mathrm{~V} の ラ$ ンプ電圧低減が可能である.

\section{4. 大型モニター・大型 TVへの対応}

\section{1 高光束化}

大型モニター・大型 TV 用途では, LCD 上輝度がノ一 トパソコンの約 3 倍以上必要である。従って，ランプも 高電流で動作させ光束を増やす必要がある．高光束を得 るにはランプ電流を増やせばよいが，大きくしすぎると ランプ温度が高くなり水銀蒸気生が上昇しすぎて光束は 飽和してしまう。

現在ではランプ管径を太くすると共に，ランプ封入が ス種・ガス压を最適化し, 高電流で動作させても光束が 飽和せずさらにバックライトの薄型化が可能である外径 $\phi 2.2 \sim 3.0 \mathrm{~mm}$ のランプが主流となっている.

\section{2 長寿命化}

大型モニター・大型 TV 用途においては，高光束を得 るために高電流で動作させ,なおかつ長寿命（50000時間 以上）が要求される. 一般的に冷陰極蛍光ランプの寿命 モ一ドは，水銀消耗による光束低下 (希ガス放電モ一ド) と蛍光体の劣化による光束低下の 2 つの一ドがある.

従来の冷陰極蛍光ランプは高電流で動作させると電極 のスパッタリングが激しくなり, 飛散した電極物質と水 銀の化合による水銀消耗が急激であった.よって，寿命 モードは水銀消耗による光束低下 (希がス放電モード) が支配的であった．今日では水銀封入量を増やす方策と して，外部より任意の水銀量を封入する方法が開発され た。

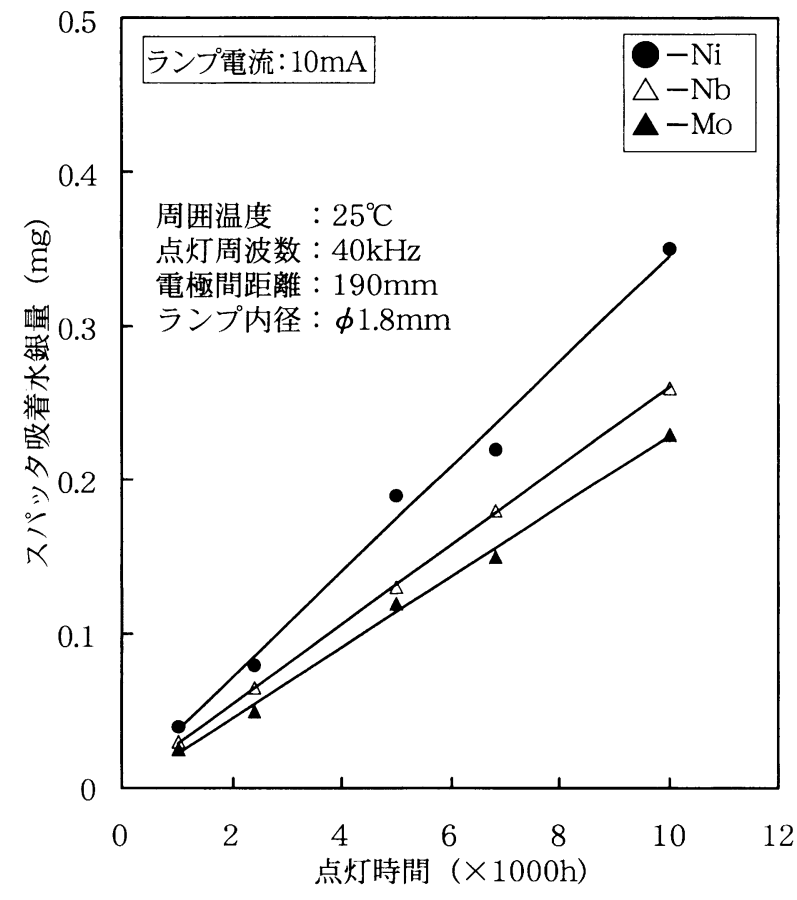

図 5 電極材質別点灯時間と水銀消耗量の関係

電極表面積の拡大は，ランプ点灯中の水銀消耗量を低 减できる，従来では製造方法の問題で電極表面積に制限 があった。しかし，現在では製造技術の改良により電極 表面積の拡大化が進み，ガラス管内径いっぱいまで大き くした電極（ガラス管内径と電極外径の隙問：0.15mm 程度)が対応可能となっている.さらに, スパッタリング しにくい電極の開発も進んでいる4). 図 5 に電極材質別 水銀消耗量の一例を示す．電極材質をMoにすることに よりスパッタリングが抑制され，長寿命化に有効である. 現在では外径 $\phi 2.4 \mathrm{~mm}$ クラスの細管蛍光ランプながら 70000時間を保証したランプが商品化されている.

今後は大型モ二ター・大型 TV 分野でも細管化・狭額 縁化による電極長の短縮化の要求があり，電極表面積・ 電極材質の改良はさらに加速するものと考えられる.

\section{3 光束維持率の向上}

LCD（液晶ディバイス）の輝度維持率はランプ自体の 光束維持率の他に LCD の構成部材であるリフレクター や導光板・拡散板の少化が相乗され低下する。従って, 冷陰極䖢光ランプの光束維持率に比べ，バックライトの 輝度維持率はさらに低下することになる。大型モ二 夕一大型 TV 用途の場合, 要求寿命時間は50000時間以 上と長く，従来の冷㓌極蛍光ランプのこの時の光束維持 率は55〜 60\%でありバックライトとしての輝度維持率 は50\%を切る可能性がある。この対策として

（1） ガラ又管内面への保護膜，监光体粒子間への保護膜 形成によるガラス管着色防止

（2）蛍光体の組成改良・表面処理・製造技術の改良によ る蛍光体少化防止 
（3）電極表面積拡大，電極材質の改良による電極のス パッタリング抑制

などの開発が進められている5).

図 6 に従来のランプと上記(1)〜 (3)の手段を施したバッ クライトの輝度維持率を示す。従来品に比べ約 $15 \%$ の維 持率の改善がされているが，CRT 置き換えのためには さらなる光束維持率の改善が必要である.

\section{4 高効率化}

オフィス・家庭生活に浸透してきた大型モニター・大 型 TV 用途においても，最近では，より一層の高効率化 要求が強く, モバイル機器や中小型民生機器と同様な曲 げ管で，かつ，長尺タイプのランプが採用され始めてい る. 図7にエッジライト方式で直管ランプを片側 2 本(両 側 4 本) と L 字管ランプを 4 本使用した場合，さらに図

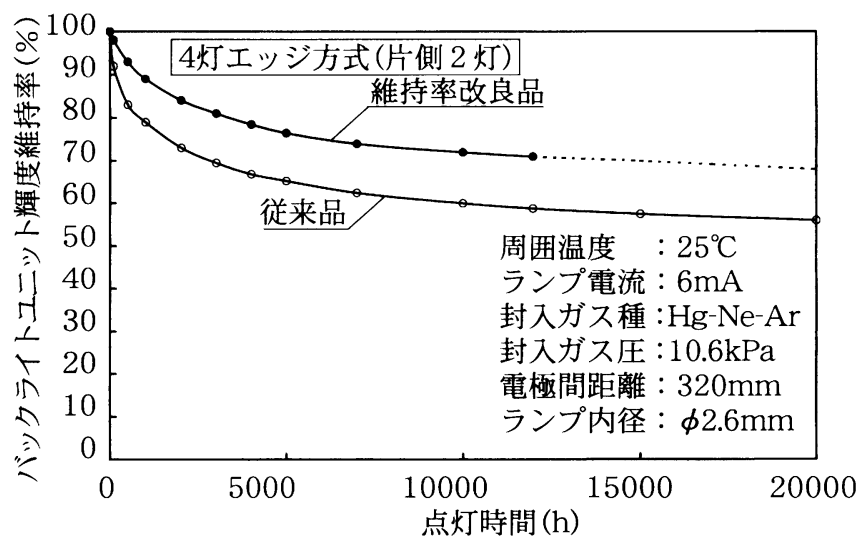

図 6 バックライトユニット輝度維持率特性

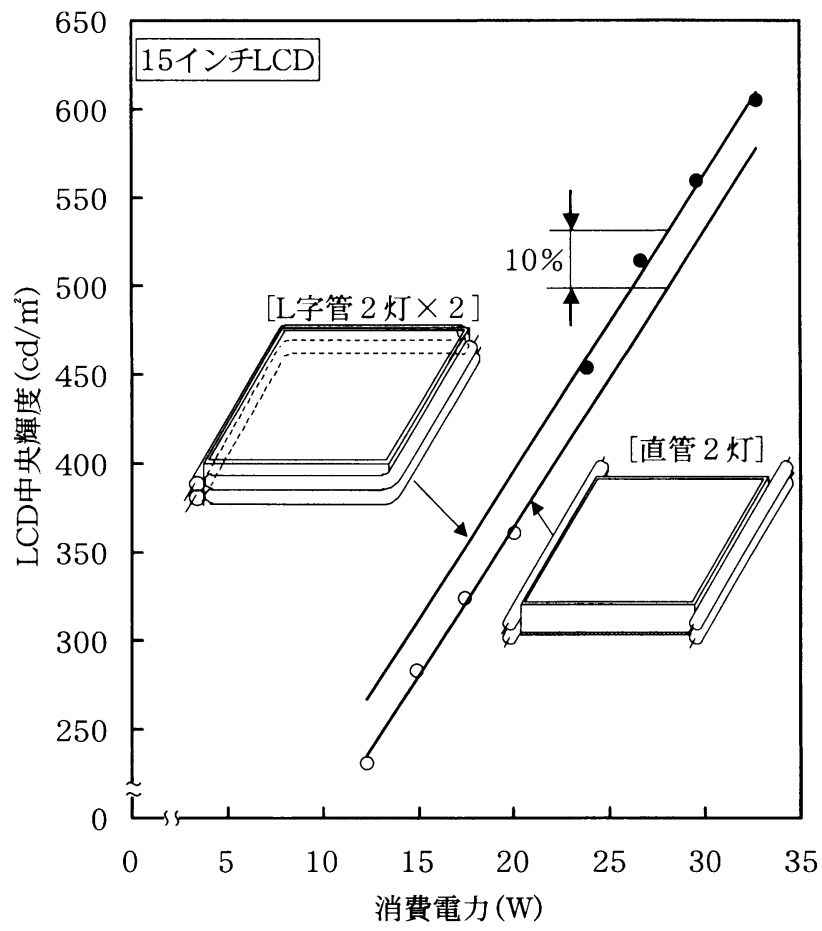

図 7 消費電力別 LCD 輝度特性

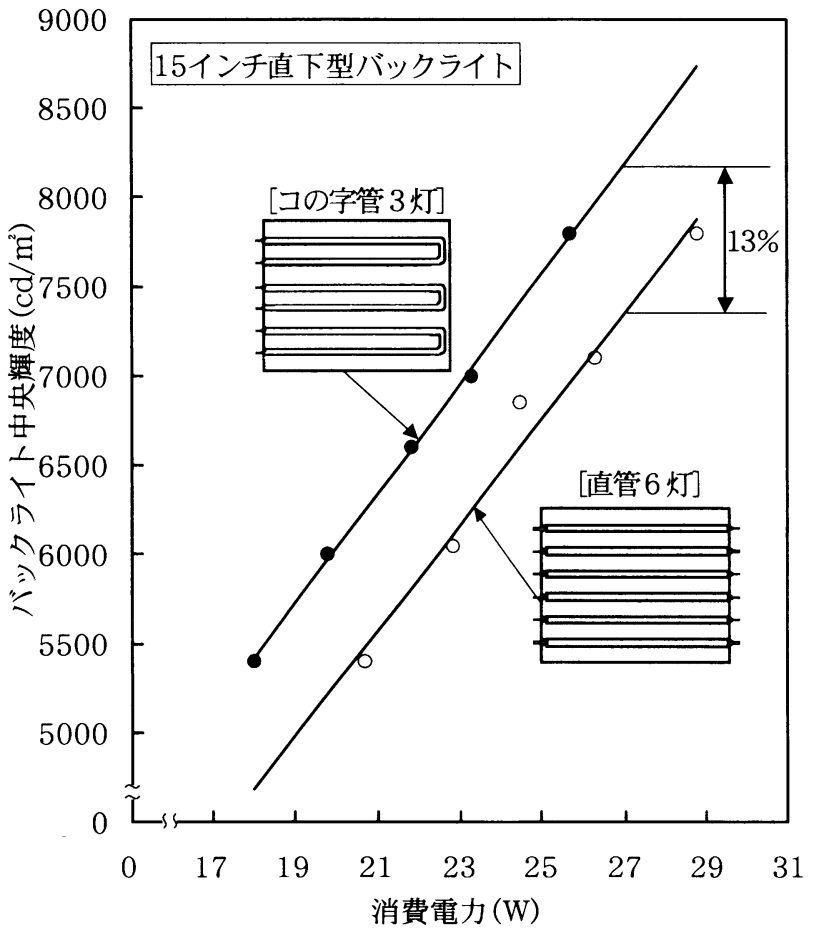

図 8 消費電力別バックライト輝度特性

8 に直下方式で值管ランプ 6 本とコの字管ランプ 3 本使 用した場合のそれぞれの消費電力別 LCD 輝度特性・ バックライト輝度特性を示す，冷㓌極蛍光ランプは電極 部で消費される電力が大きいため，ランプ効率（全光束 ノランプ電力）はランプ長が長いほど有利になる。従っ て，L字管ランプやコの字ランプを使用する方がバック ライト上でも高效率となり，また，ランプ本数を減らす ことができるのでバックライトのコストダウンも可能と なる。

しかし，本手法はランプ1本あたりの始動電圧・ラン プ電圧の上昇を招くため，開発・設計にあたっては長尺 ランプの配置方法・点灯回路・ユニット設計を含めた総 合的な設計開発が重要である。

\section{5 外部電極冷陰極蛍光ランプ (EEFL)}

最近，内部電極の替わりにランプ雨端のガラス管外壁 に電晸を設け，ガラス管壁をキャパシタンスとして利用 する誘電体バリア放電型蛍光ランプ (EEFL : External Electrode Fluorescent Lamp）の開発が進められてい る6). 従来の冷陰杫蛍光ランプはランプ 1 本に対し個々 に高周波点灯回路（インバーター）が必要であるのに比 べ，EEFLではランプ個々がキャパシタンスバラストを 持つことになるため，インバーター 1 台で多数の EEFL を点灯することができる。

発光効率は従来の冷陰極蛍光ランプと同等であるが， 高輝度を要求される多灯使用のバックライトにはシステ ムトータルでコストダウンが可能となり，主として大型 LCD 用バックライト光源として採用が検討されてい る7)8). 図 9 に EEFL を多灯使用した場合の一例を示す。 


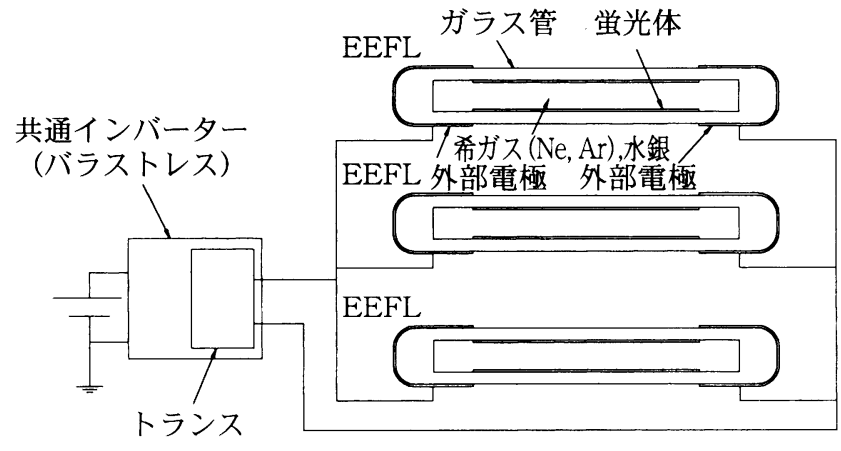

図 $9 E E F L$ の多灯使用例

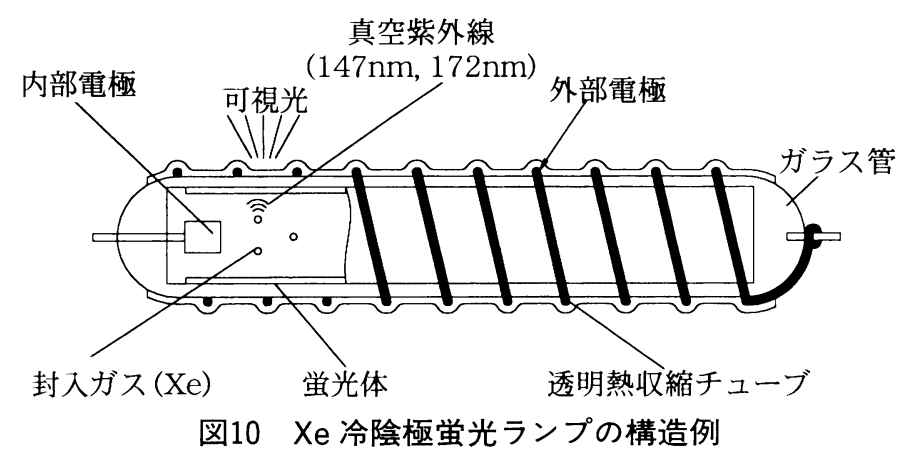

\section{6 色再現範囲の拡大}

泠㓌極蛍光ランプを LCD バックライト光源として用 いる場合, 従来は発光効率（高効率）が最重要項目であ ク，蛍光体も発光効率のよい蛍光体が採用されてきた。 標準的な $R \cdot G \cdot B$ 䖢光体の組成を示す.

$R: \mathrm{Y}_{2} \mathrm{O}_{3}: \mathrm{Eu}$

$G: \mathrm{LaPO}_{4}: \mathrm{Ce}, \mathrm{Tb}$

$B: \mathrm{BaMg}_{2} \mathrm{Al}_{15} \mathrm{O}_{27}: \mathrm{Eu}$

これらの蛍光体を用いた冷㓌極䖺光ランプをカラー LCD ディスプレイに組み込んだ場合の色再現範囲を NTSC 規格と比較すると, 色再現範讲が狭く, 特に R, Gが劣っている.

この対策方法として，より色純度の高い $\mathrm{R}, \mathrm{G}$ の蛍光 体を使用する方法があるが，標準的な蛍光体を使用した 場合に比べ約 $65 \%$ の光束しか得られない.CRTにとっ て替わるためには色再現範囲の拡大は重要項目のひとつ であり, 現行亚みの発光効率を維持しつつ色再現範囲を 拡大できる新しい蛍光体の開発が待望されている.

\section{5. 環境問題への対応}

LCD ディスプレイを構成している部品として冷陰極 蛍光ランプにも環境保全の要求がある. 冷㓌極蛍光ラン プに使用される材料で環境への影響が懸念される物質は ガラス管とはんだに含まれている鉛，及びランプ内に含 まれている水銀である ${ }^{9}$ ．鉛についてはガラス管の鉛フ リ一化，および，はんだの鉛フリ一化，または，はんだ 以外の接続方法への転換が進められている。 ランプ内の 水銀についてはランプデザインの改良による水銀消耗量 の低減化，封入水銀量のバラツキ制御などで含有水銀量 の低減化が進められている。

近年では環境保全の立場から水銀を使用しない泠㓌極 蛍光ランプが望まれており，この解決方法として水銀の 代わりに希がス $(\mathrm{Xe}$ ガスなど)を封人したランプの開発 が活発化している。形状としては平面型や管型がある.

$\mathrm{Xe}$ タイプの冷㓌極蛍光ランプは水銀タイプに比べ発光 効率が劣るが, 電極構造や点灯方法の工夫, 蛍光体の改 良などで, 効率は水銀冷除極监光ランプの65\%程度まで 上昇してきた。さらに, Xe ガス放電特有の周囲温度に影 響されない発光効率，光出力の早い立ち上がりなどのメ リットもあり，車載用を中心にまもなく市場投入される と予想される. 図10に一方の管端部に内部電晸を配置し, もう一方の電極としてらせん状の外部電極を組み合わせ た Xe 泠除極蛍光ランプの構造例を示寸 ${ }^{10)}$.

\section{6.まとめ}

以上 $\mathrm{LCD}$ バックライト用冷陰橄蛍光ランプの技術 動向について述べてきた. LCD ゙゙ィスプレイは様々な分 野で使用され続けていくと考えられるが, LED や有機 EL などの他光源もバックライト光源として実用化が進 んでいる. 今後も冷㓌極蛍光ランプが LCD バックライ 卜用光源の主流としてあり続けるためには，より一層の 性能・効率改善はもちろん省エネルギー・省資源化に対 态した高効率・長寿命化の開発がより重要になると考之 られる。

\section{参考文献}

(1) 富田ほか：H 9 照学全大, p.230 (平 9).

(2) Noguchi, H. et al. : SID 98, pp.243-246 (1998).

(3) 池田ほか：平成 9 年度電気関係学会四国支部連合大会 p.88（平 9 ).

（4）菅原ほか：H13年照学全大, p.57 (平13).

(5) Nishihara, T. et al. : IDW 00, pp.379-382 (2000).

(6) Takeda, Y. et al. : SID 02, pp.346-349 (2002).

(7) H-S.Kim. et al. : SID 01, pp.687-689 (2001).

(8) N-O.Kwon. et al. : Asia IDW 01, pp.687-689 (2001).

（9）照明学会編：平成 9 年「環境保全と照明システム」, 環境保全のた めの照明システム研究調査委員会 (平 9).

(10) 矢野ほか：H12照学全大, p.55 (平12). 